\title{
Effects of adrenergic drugs on aqueous humour dynamics in the normal human eye. I. Salbutamol
}

\author{
R. L. COAKES' AND P. B. SIAH ${ }^{2}$ \\ From the 'Glaucoma Unit, Moorfields Eye Hospital, High Holborn, London WC1, and the \\ ${ }^{2}$ Department of Optometry, City University, London EC1
}

SUMmaRY The immediate effects of topical salbutamol, a beta $a_{2}$ adrenergic agonist, on the aqueous humour dyamics of 22 normal subjects was studied by fluorophotometry and tonography. Significant lowering of intraocular pressure was accompanied by a significant increase in both aqueous flow rate and tonographic facility of outflow. Uveoscleral outflow was calculated and found to be significantly increased by salbutamol. This appeared to be the predominant acute pressure lowering effect of beta receptor stimulation in the normal human eye.

Pharmacological manipulation of the adrenergic system within the eye plays an important part in the medical treatment of glaucoma. Timolol and adrenaline are widely used as ocular hypotensive agents and highlight the apparent paradox that both stimulation and blockade of adrenoceptors result in lowering of the intraocular pressure.

Fluorophotometric studies' ${ }^{12}$ have shown that timolol, a beta $a_{1}$ and beta $a_{2}$ antagonist lowers the intraocular pressure by reducing the rate of aqueous formation. It has little or no effect on aqueous outflow. ${ }^{34}$ Recent studies ${ }^{56}$ on the effect of adrenaline, a mixed alpha, beta ${ }_{1}$, and beta ${ }_{2}$ agonist, have revealed more complex actions. Intraocular pressure is reduced, in spite of an increase in aqueous formation, by an increase in aqueous outflow, which appears to be predominantly through the uveoscleral pathway. Bill $^{7}$ had earlier found a similar effect in monkeys with isoprenaline, a predominantly beta agonist. This increase in uveoscleral outflow is thought to be due to beta receptor mediated ciliary muscle relaxation.

Salbutamol is a relatively specific beta $a_{2}$ agonist that has been shown to have a significant ocular hypotensive effect in man. ${ }^{8}$ It was considered a suitable drug for investigating the effects of beta receptor stimulation on aqueous humour dynamics in the normal human eye.

Correspondence to Mr R. L. Coakes, King's College Hospital, Denmark Hill, London SE5 9RS.

\section{Subjects and methods}

Twenty-two normal, young subjects, 13 male and 9 female, participated in the study. Each subject underwent a full eye examination and met the admission criteria that both eyes were normal except for ametropia and that the intraocular pressure of the two eyes differed by $3 \mathrm{mmHg}$ or less.

The study was divided into two parts separated by a minimum period of two weeks. In the first part the effect of salbutamol on aqueous flow was measured by fluorophotometry; in the second part the effect on tonographic facility of outflow was measured.

In both parts of the study each subject acted as his or her own control, receiving randomly assigned drug solution to one eye and placebo solution to the other. The study was carried out in a double-masked fashion.

Salbutamol sulphate solution, equivalent to $4 \%$ salbutamol base, and placebo vehicle solution were prepared by the hospital pharmacy and placed in drug-placebo bottle pairs labelled according to a code retained by the pharmacy until the end of the study.

\section{FLUOROPHOTOMETRIC STUDY}

On the morning of the study the volume of the anterior chamber of each eye was determined by a photogrammetric method," and the intraocular pressures were measured by Goldmann applanation tonometry. One $50 \mu \mathrm{l}$ drop of the drug or placebo solution was then placed in the appropriate con- 
junctival sac. One hour later a mass of fluorescein of between 0.15 and $0.7 \mu \mathrm{g}$ was introduced into the central $4 \mathrm{~mm}$ of the corneal stroma by iontophoresis and surface fluorescein removed by irrigation with balanced salt solution.

Fluorescein concentration was measured in the cornea and anterior chamber 20 minutes after iontophoresis and at two and seven hours with a xenon flash fluorophotometer." ${ }^{10}$ The mass of fluorescein in the cornea was measured 30 minutes after iontophoresis. The anterior chamber volume and intraocular pressure of each eye were measured after the seven-hour fluorophotometric reading.

The fluorophotometric and anterior chamber volume data were used to calculate the anterior chamber elimination coefficient, $K_{c}$ and the rate of aqueous flow, F, by a nomographic method."

\section{TONOGRAPHIC STUDY}

All 22 subjects who had participated in the aqueous flow study later underwent tonography. On the morning of the study the intraocular pressure of each eye was measured by Goldmann applanation tonometry and four-minute tonography was carried out with a $5.5 \mathrm{~g}$ weight. One drop of drug or placebo solution, from the same bottles used in the fluorophotometric study, was placed in each conjunctival sac. Five hours later applanation tonometry and tonography were repeated.

IRIS DIFFUSION STUDY

A separate fluorophotometric study was carried out to determine the effect of salbutamol on the permeability of the iris vessels to fluorescein. Two young, normal male subjects participated in a crossover study. One drop of drug or placebo solution was placed in each conjunctival sac. One hour later $1 \mathrm{~g}$ of sodium fluorescein in $150 \mathrm{ml}$ of water was taken orally. The fluorescein concentration in the anterior chamber of each eye and in the serum ultrafiltrate was measured every 30 minutes for 4 hours. The transfer coefficient for fluorescein by diffusion, $\mathrm{K}_{\mathrm{d}}$, was determined from these data and from the pre- viously determined values for $\mathrm{K}_{\mathrm{c}}$ by a modification of the method described by Nagataki. ${ }^{12}$

The relationship between aqueous inflow and aqueous outflow is given by the equation

$$
F=C\left(P_{0}-P_{c v}\right)+U \ldots \ldots \ldots \ldots \ldots \ldots \ldots \ldots \ldots \ldots,
$$

where $\mathrm{F}$ is the rate of aqueous inflow, $\mathrm{C}$ the tonographic facility of outflow, $P_{o}$ the intraocular pressure, $P_{\mathrm{cv}}$ the episcleral venous pressure, and $U$ the pressure-insensitive uveoscleral outflow.

The pressure-sensitive aqueous outflow $\left(F_{\text {trat }}\right)$ was calculated according to the equation

$$
F_{\text {trah }}=C\left(P_{o}-P_{c v}\right) \ldots \ldots \ldots \ldots \ldots \ldots \text { (2). }
$$

A value of $8 \mathrm{mmHg}$ was assumed for $P_{\mathrm{cv}}$ and the means of the initial and the final intraocular pressures from the fluorophotometric and tonographic studies were taken for $\mathrm{P}_{\mathrm{o}}$.

The pressure-insensitive uveoscleral outflow (U) was calculated according to the equation

$$
\mathrm{U}=\mathrm{F}-\mathrm{F}_{\text {trah }} \ldots \ldots \ldots \ldots \ldots \ldots \text { (3). }
$$

Statistical analysis of the results of the fluorophotometric and tonographic studies was carried out by Student's $t$ test.

\section{Results}

Table 1 gives the results of the aqueous flow study. Table 2 gives the results of the outflow facility study. Statistical analysis of both studies is given in Table 3 .

Salbutamol-treated eyes showed a statistically significant increase in aqueous flow rate of $39 \%$ and a statistically significant decrease in intraocular pressure compared with the placebo-treated eyes. Facility of outflow increased by $42 \%$ in the salbutamol-treated eyes but also increased significantly, by $21 \%$, in the placebo-treated eyes.

Calculated values for trabecular outflow $\left(F_{\text {traib }}\right)$ and

\begin{tabular}{|c|c|c|c|c|c|c|c|}
\hline & & \multicolumn{2}{|c|}{$\begin{array}{l}\text { Intraocular pressure } \\
\text { (minHg) }\end{array}$} & \multicolumn{2}{|c|}{$\begin{array}{l}\text { Anterior chamber } \\
\text { volume }(\mu L)\end{array}$} & \multirow{2}{*}{$\begin{array}{l}\text { Anterior chamber } \\
\text { elimination } \\
\text { coefficient Ke } \\
\left(\mathrm{min}^{-1} \times 10^{2}\right)\end{array}$} & \multirow[t]{2}{*}{$\begin{array}{l}\text { Aqueous flow } \\
\left(\mu L . \mathrm{min}^{-1}\right)\end{array}$} \\
\hline & & Initial & Final & Initial & Final & & \\
\hline \multirow[t]{3}{*}{ Salbutamol cycs } & Mcan & $15 \cdot 2$ & $11 \cdot 1$ & 213 & 213 & $1 \cdot 82$ & $3 \cdot 48$ \\
\hline & SD & $1 \cdot 62$ & $1 \cdot 80$ & $26 \cdot 5$ & $25 \cdot 1$ & 0.37 & $(0.71$ \\
\hline & SE & 0.35 & 0.38 & $5 \cdot 66$ & $5 \cdot 35$ & 0.08 & 0.15 \\
\hline \multirow[t]{3}{*}{ Placebo cyes } & Mcan & $15 \cdot 1$ & $14 \cdot 1$ & 213 & 214 & $1 \cdot 38$ & $2 \cdot 61$ \\
\hline & SD & 1.65 & $2 \cdot 23$ & $26 \cdot 5$ & $26 \cdot()$ & 0.42 & 0.69 \\
\hline & SE & 0.35 & 0.48 & $5 \cdot 65$ & $5 \cdot 55$ & $0 \cdot() 9$ & 0.15 \\
\hline
\end{tabular}
uveoscleral outflow are given in Table 4.

Table 1 Fluorophotometric results

Numbers of subjects $=22,13 \mathrm{M}: 9 \mathrm{~F}$, average age $21 \cdot 2$ ycars $($ range $18 \cdot 7-28 \cdot())$. 
Table 2 Tonographic results

\begin{tabular}{|c|c|c|c|c|c|}
\hline & & \multicolumn{2}{|c|}{$\begin{array}{l}\text { Intraocular } \\
\text { pressure }(\mathrm{mm} \mathrm{mg})\end{array}$} & \multicolumn{2}{|c|}{$\begin{array}{l}\text { Outflow facility } \\
\left(\mu L . \min ^{-1} \text { mm } \mathrm{Hg}^{-1}\right)\end{array}$} \\
\hline & & Initial & 5 hours & Initial & 5 hours \\
\hline \multirow[t]{3}{*}{ Salbutamol cyes } & Mcan & $13 \cdot 6$ & 10.1 & 0.24 & ()$\cdot 34$ \\
\hline & SD & 1.97 & 1.89 & $0 .(18$ & 0.08 \\
\hline & $\mathrm{SE}$ & $(1) \cdot 42$ & $(0 \cdot 40$ & $0 .(02$ & $0 \cdot() 2$ \\
\hline \multirow[t]{3}{*}{ Placebo cyes } & Mcan & $13 \cdot 8$ & $13 \cdot 1$ & 0.24 & 0.29 \\
\hline & SD & 1.95 & 1.54 & $0 .(07$ & $0 \cdot(08$ \\
\hline & SE & 0.42 & 0.33 & $0 \cdot() 1$ & $0 \cdot(1) 2$ \\
\hline
\end{tabular}

Table 3 Statistical analysis

\begin{tabular}{|c|c|c|c|}
\hline & & $t$ & $p$ \\
\hline \multicolumn{4}{|c|}{ Fluorophotometric study } \\
\hline 1. Flow rate & $\mathrm{S}-\dot{\mathrm{P}}$ & 5.92 & $<0.001$ \\
\hline \multirow{4}{*}{$\begin{array}{l}\text { 2. Intraocular } \\
\text { pressure }\end{array}$} & $S_{1}-S_{\Gamma}$ & $14 \cdot 34$ & $<() \cdot()) 1$ \\
\hline & $P_{1}-P_{1}$ & $3 \cdot 10$ & $<() \cdot(0)$ \\
\hline & $P_{1}-S_{1}$ & $1 \cdot 70$ & NS \\
\hline & $P_{1}-S_{1}:$ & 10.77 & $<() \cdot(0) 1$ \\
\hline \multicolumn{4}{|c|}{ Tonographic study } \\
\hline \multirow{4}{*}{$\begin{array}{l}\text { 1. Outflow } \\
\text { facility }\end{array}$} & $S_{1}-S_{1}$ & 6.91 & $<() \cdot()())$ \\
\hline & $P_{1}-P_{1}$ & $3 \cdot 22$ & $<0 \cdot(0) 1$ \\
\hline & $P_{1}-S_{1}$ & 0.60 & NS \\
\hline & $S_{\mathrm{F}}-\mathrm{P}_{\mathrm{F}}$ & $2 \cdot 86$ & $<() \cdot() 1$ \\
\hline \multirow{4}{*}{$\begin{array}{l}\text { 2. Intraocular } \\
\text { pressure }\end{array}$} & $S_{1}-S_{F}$ & $9 \cdot 75$ & $<() \cdot(x) 1$ \\
\hline & $P_{1}-P_{F}$ & 2.94 & $<0) \cdot(0)$ \\
\hline & $P_{1}-S_{1}$ & $1 \cdot 31$ & NS \\
\hline & $P_{\mathrm{F}}-\mathrm{S}_{\mathrm{r}}$ & $8 \cdot 38$ & $<() \cdot(x) 1$ \\
\hline
\end{tabular}

$S=$ Salbutamol cyc. $P=$ Placebo eyc. $I=$ Initial measurement. $F=$ Final measurement. NS $=$ Not significant $(p>0 \cdot(15)$.

The results of the iris diffusion study are given in Table 5. Fluorescein loss from the anterior chamber increased by approximately one-third in the salbutamol-treated eyes.

\section{Discussion}

The results of this study show that the immediate effect of salbutamol is to increase the rate of flow of aqueous humour and to increase the rate of outflow. The net effect of these conflicting actions is to lower intraocular pressure.

The rate of flow of aqueous humour has been calculated on the assumption that $90 \%$ of fluorescein loss from the anterior chamber is by bulk flow and the
Table 5 Iris diffusion study

\begin{tabular}{|c|c|c|c|c|}
\hline \multirow[b]{2}{*}{ Subject } & \multicolumn{2}{|c|}{ Salbutamol } & \multicolumn{2}{|c|}{ Placebo } \\
\hline & Eye & $\begin{array}{l}\text { Diffusion coefficient } \\
\left(K_{d}\right)=I 0^{:}\end{array}$ & Eye & $\begin{array}{l}\text { Diffusion coefficient } \\
\left(K_{l}\right)=10^{3}\end{array}$ \\
\hline A & $\mathrm{L}$ & $1 \cdot 14$ & $\mathrm{R}$ & (1).69) \\
\hline A & $\mathrm{R}$ & $1 \cdot(1) 2$ & L & $(1.73$ \\
\hline B & $\mathrm{L}$ & 0.52 & $\mathrm{R}$ & 0.55 \\
\hline B & $\mathrm{R}$ & 0.80 & $\mathrm{~L}$ & 0.62 \\
\hline Mcan & & 0.87 & & 0.65 \\
\hline SD & & 0.27 & & 0.08 \\
\hline SE & & 0.14 & & $0 .(14$ \\
\hline
\end{tabular}

remainder by diffusion. This is true for the normal, undisturbed eye, but topically applied drugs may alter iris vessel permeability and thus increase or decrease diffusional losses of fluorescein leading to an over- or underestimation of aqueous flow rate. The experiments with oral fluorescein indicate that salbutamol increases diffusional losses by about a third; if this is taken into consideration, aqueous flow rate is increased by salbutamol by $35 \%$. These results are in close agreement with the findings of Araie and Takase, ${ }^{13}$ who studied the effect of DL-metaproteranol, a beta agonist, in normal human eyes. They found that diffusion losses were increased by $14 \%$ and aqueous flow rate by $35 \%$

Stimulation of aqueous formation by salbutamol is consistent with the effect of timolol, a beta, and beta $_{2}$ adrenoceptor antagonist. Earlier fluorophotometric studies have shown that timolol reduces aqueous flow rate by between $34 \%^{\prime}$ and $47 \%{ }^{2}$ probably by blocking the action of noradrenergic stimulation or circulating catecholamines at adreno-

Table 4 Calculated trabecular and uveoscleral outflow

\begin{tabular}{|c|c|c|c|c|c|c|c|}
\hline & & \multicolumn{3}{|c|}{ Salbutamol eyes } & \multicolumn{3}{|c|}{ Placebo eyes } \\
\hline & & Mean & $S D$ & $S E$ & Mean & $S D$ & $S E$ \\
\hline \multirow{3}{*}{$\begin{array}{l}\text { Trabecular outflow } \\
\left(F_{\text {trath }}\right) \mu l \text { min }^{-1} \\
\text { Uveoscleral outflow (U) } \\
\mu l \text { min }^{-1}\end{array}$} & Pre-treatment & 1.54 & 0.61 & $0 \cdot 13$ & 1.54 & 0.50 & 0.11 \\
\hline & Treated & $(0 \cdot 84$ & 0.50 & 0.11 & 1.55 & $0 \cdot 43$ & $0 .(09$ \\
\hline & & 2.59 & 0.84 & 0.18 & 1.06 & 0.75 & 0.16 \\
\hline
\end{tabular}


ceptors located in the ciliary processes. Nathanson ${ }^{14}$ has shown that in man, as in lower species, these adrenoceptors are predominantly of the beta $a_{2}$ subgroup, and they might be expected to be particularly sensitive to the effect of salbutamol, a relatively specific beta 2 agonist. Ueno et al. ${ }^{15}$ showed that topical salbutamol induces morphological changes in the non-pigmented cells of the rabbit ciliary epithelium indicative of increased cellular activity, suggesting that the beta adrenergic drugs exert an influence on the secretory component of aqueous formation. There is no convincing evidence to date of a vascular mediated effect, though beta-receptorinduced changes in the calibre of the afferent arterioles supplying the ciliary processes would modify the rate of aqueous formation by altering ultrafiltration.

The effect of salbutamol on aqueous outflow is more complex. For the purpose of calculating outflow through the trabecular meshwork and through the uveoscleral route a value of $8 \mathrm{mmHg}$ has been assumed for the episcleral venous pressure which was not measured in the study. Further, it has been assumed that salbutamol does not significantly alter $\mathbf{P}_{\mathrm{cv}}$. Careful and repeated measurements by Kupfer and his co-workers ${ }^{16-18}$ failed to show any significant effect of adrenergic agonists, including the predominantly beta agonist isoprenaline, on $P_{\mathrm{cv}}$ after one hour. Transient but unimportant effects may have occurred, and delayed effects after one hour cannot be ruled out, but it seems unlikely that topically applied beta agonists cause a significant reduction in $\mathbf{P}_{\text {cv. }}$ :

The increase in tonographic facility of outflow with salbutamol is consistent with the finding of Langham and Diggs ${ }^{10}$ that a $2 \%$ solution results in a $60 \%$ increase in $\mathrm{C}$ at 6 hours. Paterson and Paterson, using a $4 \%$ solution, found little or no change in $C$, but their measurements were taken at the end of one and two weeks' treatment. The significant increase in $C$ that occurred in our placebo-treated eyes was unexpected and did not occur in the study by Langham and Diggs. In other studies ${ }^{17}$ tonography repeated after a period as short as one hour has given identical results, and it is concluded that the significant increase in $\mathrm{C}$ in the control eye is drug induced, though the mechanism of this consensual response remains obscure.

In the placebo-treated eyes trabecular outflow $\left(F_{\text {trith }}\right)$ was unchanged in spite of the increase in $C$, because $P_{o}$ fell during the course of the study. By contrast $F_{\text {trath }}$ was reduced by $47 \%$ in the salbutamoltreated eyes-that is, less aqueous left these eyes via the pressure-dependent trabecular route despite the substantial increase in outflow facility.

For the purpose of calculating uveoscleral outflow it has been assumed that the facility of outflow measured at five hours is attained within one hour of instilling salbutamol and similarly the final intraocular pressures in the tonographic and fluorophotometric studies. The apparent increase in U in the salbutamoltreated eyes is approximately $160 \%$, and more than three times the volume of aqueous leaves the salbutamol-treated eye by this pressure-insensitive route than via the trabecular meshwork and canal of Schlemm. Townsend and Brubaker ${ }^{5}$ in their fluorophotometric study of the acute effect of adrenaline calculated that $U$ had increased by $58 \%$ while $F_{\text {trith }}$ was unchanged.

The results of this study indicate that beta receptors are present in the ciliary processes, the ciliary muscle, and trabecular meshwork of the human eye. Stimulation results in an immediate increase in aqueous formation, uveoscleral outflow, and tonographic facility of outflow. These effects are similar to those produced by adrenaline, suggesting that at least in the short term the beta $a_{2}$ agonist effect of adrenaline is dominant.

We gratefully acknowledge the gencrous support of the T.F.C. Frost charitable trust for this study. P.B. Siah was also supported through the Chappell glaucoma scholarship. We thank Mr Bob Watkins and Miss Jill Bloom of the Moorficlds Pharmacy for the preparation of matcrials for this study and Miss Eilcen Creaby for secretarial assistance.

\section{References}

1 Coakes RL, Brubaker RF. The mechanism of timolol in lowering intraocular pressurc. Arch Ophthalmol 1978; 96: 2(145-8.

2 Yablonski ME, Zimmerman TJ, Waltman SR, Becker B. A fluorophotometric study of the effect of topical timolol on aqueous humour dynamics. Exp Eye Res 1978; 27: 135-42.

3 Sonntag JR, Brindlcy GO, Shiclds MB. Effect of timolol therapy on outflow facility. Invest Ophthalmol Visual Sci 1978; 17: 293-6.

4 Zimmerman TJ, Harbin R, Pctt M, Kaufman HE. Timolol and facility of outflow. Invest Ophthalmol Visual Sci 1977; 16: 623-4.

5 Townsend DJ, Brubaker RF. Immediate effect of epinephrine on aqueous formation in the normal human cye as measured by fluorophotometry. Invest Ophthalmol Visual Sci 1980; 19: 256-66.

6 Schenker HI, Yablonski ME, Podos SM, Linder L. Fluorophotometric study of cpincphrinc and timolol in human subjects. Arch Ophthalmol 1981; 99: 1212-6.

7 Bill A. Effects of norepinephrine, isoproterenol and sympathetic stimulation on aqueous humour dynamics in vervet monkcys. Exp Eye Res 1970); 10: 31-45.

8 Paterson GD. Paterson G. Drug therapy of glaucoma. Br J Ophthalmol 1972: 56: 288-94.

9 Johnson SB. Cọaks RL, Brubaker RF. A simple photogrammatric method of measuring anterior chamber volume. A $m \boldsymbol{J}$ Ophthalmol 1978; 85: 469-74.

10 Brubaker RF, Coakes RL. Uses of a xenon flash tube as the excitation source in a new slit-lamp fluorophotometer. Am J Ophthalmol 1978; 86: 474-84.

11 Coakes RL, Brubaker RF. Method of measuring aqueous humour flow and corncal endothelial permeability using a fluorophotometry nomogram. Invest Ophthalmol Visual Sci 1979; 18: $288-302$. 
12 Nagataki S. Aqueous humour dynamics in human cyes as studied using fluoresccin. Jpn J Ophthalmol 1975; 19: 235-49.

13 Araic $M$, Takase $M$. Effects of various drugs on aqueous humour dynamics in man. Jpn J Ophthalmol 1981; 25: 91-113.

14 Nathanson JA. Human ciliary process adrenergic receptor: pharmacological characterization. Invest Ophthalmol Visual Sc $1981 ; 21: 798-804$.

15 Ueno K. Tamura T. Mishima S. Effects of adrenergic drugs on the ciliary epithelium of albino rabbits. Metab Ophthalınol 1977; 1: 199-207.

16 Kupfer C, Gaasterland D, Ross K. Studies of aqueous humour dynamics in man. II. Measurements in young normal subjects using acctazolamide and L-epincphrinc. Invest Ophthalmol Visual Sci 1971; 10: 523-33.

17 Gaasterland D, Kupfer C, Ross K, Gabelnick HL. Studies of aqueous humour dynamics in man. III. Mcasurements in young normal subjects using norepinephrine and isoproterenol. Invest Ophthalınol Visual Sci 1973; 12: 267-79.

18 Kupfer C. Gaasterland D, Ross K. Studies of aqueous humour dynamics in man. V. Effects of acetazolamide and isoproterenol in young and old normal voluntecrs. Invest Ophthalmol Visual Sci 1976; 15: 349-55.

19 Langham ME, Diggs $E$. $\beta$-Adrenergic responses in the cyes of rabbits, primates and man. Exp Eye Res 1974; 19: 281-95. 